\title{
Influence of bagasse versus rice straw with oil sources in a total mixed ration on feed intake, digestibility and blood chemistry of crossbred Thai Native $x$ American Brahman cattle
}

\author{
I. Amartsana ${ }^{1}$, N. Prakobsaeng ${ }^{2}$ and W. Polviset ${ }^{2, *}$ \\ ${ }^{1}$ Program in Agricultural Technology, Faculty of Agricultural Technology, \\ Rajabhat Maha Sarakham University, Maha Sarakham, 44000 - Thailand \\ ${ }^{2}$ Program in Animal Science, Faculty of Agricultural Technology, \\ Rajabhat Maha Sarakham University, Maha Sarakham, 44000 - Thailand \\ *Corresponding E-mail: polviset@hotmail.com
}

Received May 26, 2020; Accepted July 07, 2020

\begin{abstract}
ABSTRAK
Tujuan penelitian ini adalah menganalisis efek sumber serat dan sumber minyak dalam ransum campuran total (RCT) pada asupan pakan sukarela, kecernaan dan kimia darah. Penelitian dilakukan menggunakan empat sapi hasil persilangan Thai native x American Brahman, berumur 1,5 tahun dengan bobot badan $177 \pm 34 \mathrm{~kg}$ yang diujicobakan dengan menggunakan factorial $2 \times 2$ dalam desain bujur sangkar latin $4 \times 4$. Semua ternak memperoleh diet RCT yang dilengkapi ampas tahun dan minyak kelapa sawit, ampas tahun dan minyak bunga matahari, jerami padi dan minyak kelaapa sawait, jerami padi dan bunga matahari. Setiap periode berlangsung selama 21 hari, semua sapi diberi makan ad libitum dan persedian air yang tidak terbatas. Hasil penelitian menunjukkan bahwa sumber serat dan sumber minyak tidak mempengaruhi asupan pakan sukarela, kecernaan dan kimia darah. Disimpulkan bahwa ampas tahu atau jerami sebagai sumber serat dengan minyak kelapa sawit dan bunga matahari yang dicampur dadalam TMR cocok digunakan dalam pakan sapi potong, terutama ampas tahu dengan minyak kelapa sawit karena menunjukkan harga terendah $(0,28 \mathrm{USD} / \mathrm{kg})$.
\end{abstract}

Kata kunci : sumber serat, sumber minyak, pakan campuran total, sapi potong

\begin{abstract}
This study was aimed to analysis the effects of roughage sources and oil sources in a total mixed ration (TMR) on voluntary feed intake, digestibility and blood chemistry. The study was conducted using four crossbred Thai Native X American Brahman cattle, aged 1.5 years old and with a live weight of $177 \pm 34 \mathrm{~kg}$, which were trialled by using a $2 \times 2$ factorial in $4 \times 4$ Latin square design. All cattle received TMR diets supplemented with bagasse and palm oil, bagasse and sunflower oil, rice straw and palm oil, rice straw and sunflower oil. Each period of feeding lasted for 21 days. During the experimental periods, all cattle were fed ad libitum and with a water supply. The results revealed that roughage sources and oil sources did not affect voluntary feed intake, digestibility and blood chemistry. It was concluded from this experiment that using bagasse or rice straw as the roughage sources with palm oil and sunflower oil mixed in the TMR were suitable for use in beef cattle diets, especially using bagasse with palm oil because of the lowest price $(0.28 \mathrm{USD} / \mathrm{kg})$ when compared to the other treatments.
\end{abstract}

Keywords: roughage sources, oils resources, total mixed ration, beef cattle 


\section{INTRODUCTION}

For the production of ruminants in tropical areas it is well known that huge quantities of lowquality feedstuffs such as rice straw and bagasse from biomass can be used as a potential roughage source for ruminants (Van Soest, 1994). Rice production in Asia is about 670 million tons per year (Nguyen et al., 2019) so ample sources are available, as after rice harvesting, rice straw can be produced as a feed for ruminants. In addition, bagasse is another by-product of the sugar industry used to feed ruminants and could be shown to be important for fibre utilisation in ruminants such as in buffaloes (Seshaiah et al., 2014) and goats (Baiti et al., 2013). Whereas by product from bulky nature of roughage sources restrict consumption so that livestock need additional energy supplementation according to Bauman et al. (2003) who finding sustainable sources of energy for ruminants is important and fat supplementation appears to be of benefit for increasing the diet's energy density. Moreover, the use of these kind of feedstuffs are possible to reduce operational feed cost and could increase the benefit of production. Therefore, by considering vegetable oils, this can be obtained from palm or sunflower oil. Additionally, another energy source in tropical areas always uses is cassava chips that a good source of ruminal degradation (Sommart et al., 2000).

The objective of this study was to investigate the effect of the addition of bagasse and rice straw with palm oil and sunflower oil in the TMR on voluntary feed intake, nutrient intake, digestibility and blood chemistry in crossbred Thai Native $\mathrm{x}$ Brahman bulls.

\section{MATERIALS AND METHODS}

\section{Animals and Experimental Design}

Four crossbred Thai native X Brahman bulls, with a live weight of $177 \pm 34 \mathrm{~kg}$ and aged about 1.5 years old were used in a $2 \times 2$ factorial in $4 \times 4$ Latin-square design with 21 days for each period. The bulls were treated for intestinal worms and were injected with an oily solution of $\mathrm{A}, \mathrm{D}_{3}$ and $\mathrm{E}$ vitamins before the start of the experiment. All animals were housed individually.

\section{Experimental Diets}

During each period (21 days for each period), all animal treatments were offered $a d$ libitum. TMRs were roughage: concentrate in a 40:60 ratio, in which dry fodder, especially rice straw and bagasse were chopped into $3 \mathrm{~cm}$ sizes, mixed along with concentrate in proportion to make a chemical composition as presented in Table 1. The mixing of roughage and concentrate portions of the feed was then blended together to make the TMR. The treatment consisting of bagasse and rice straw were used as the roughage sources supplemented with sunflower oil (SFO) and palm oil (PO) as the oil sources. The diets were articulated isonitrogenous and iso-TDN (14\% protein, $60 \%$ ), and the price of feeds were $8.60,8.80,9.00$ and 9.50 THB (Thai baht)/kg as shown in Table 1.

\section{Feeds, Faeces Collection and Analysis}

The experiment proceeded for 4 periods, in each period the first 14 days were an adaptation period and the last 7 days were an experimental period. The amount of TMRs offered was collected daily so that TMR refusals were weighed. All TMRs offered and refused were sampled through the experimental period and stored (at $-20{ }^{\circ} \mathrm{C}$ ) until chemical composition analyses were carried out: dry matter (DM), ash, crude protein $(\mathrm{CP})$ and ether extract (EE) (AOAC, 1984), neutral detergent fibre (NDF) and acid detergent fibre (ADF) (Goering and Van Soest, 1970). Voluntary feed intake and apparent diet digestibility were determined by the method as described by Moloney and O'Kiely (1997).

\section{Measurement of Body Weights and Blood Analysis}

The animals were weighed before and after each experimental period. In the morning before feeding, the cattle were restrained and blood was collected by puncturing the jugular vein. Blood collections were made using evacuated tubes containing anticoagulants and centrifuged at 2,500 $\mathrm{g}$ for $15 \mathrm{~min}$. All plasma samples were evaluated in commercial kits (Labtest ${ }^{\circledR}$ Diagnóstica S.A.,Lagoa Santa, MG, Brazil) to analyse plasma glucose, blood urea nitrogen (BUN), triglycerides, and cholesterol concentrations.

\section{Statistical Analysis}

All data were analysed using SAS, software version 8.0 (SAS, 2000). The PROC general linear model (GLM) procedure was used for the analysis of variance (ANOVA). Means were compared by Duncan's new multiple range test (DMRT) (Steel and Torrie, 1980). 
Table 1. Ingredients and Chemical Composition of Experimental Diets

\begin{tabular}{|c|c|c|c|c|}
\hline \multirow{2}{*}{ Ingredients(kg) } & \multicolumn{2}{|c|}{ Bagasse } & \multicolumn{2}{|c|}{ Rice Straw } \\
\hline & $\mathrm{PO}$ & $\mathrm{SO}$ & $\mathrm{PO}$ & $\mathrm{SO}$ \\
\hline \multicolumn{5}{|c|}{ Ingredients (based on 100\% DM) } \\
\hline Bagasse & 40.00 & 40.00 & - & - \\
\hline Rice straw & - & - & 40.00 & 40.00 \\
\hline Palm kernel cake & 10.00 & - & 17.00 & - \\
\hline Sunflower meal & - & 11.00 & - & 12.00 \\
\hline Soy bean meal $44 \% \mathrm{CP}$ & 7.00 & 7.00 & 7.00 & 6.50 \\
\hline Cassava chip & 35.50 & 35.50 & 29.50 & 35.00 \\
\hline Palm oil & 1.50 & - & 1.00 & - \\
\hline Sunflower oil & - & 1.00 & - & 1.00 \\
\hline Urea & 3.50 & 3.00 & 3.00 & 3.00 \\
\hline Dicalcium phosphate & 1.00 & 1.00 & 1.00 & 1.00 \\
\hline Limestone & 1.00 & 1.00 & 1.00 & 1.00 \\
\hline Premix & 0.30 & 0.30 & 0.30 & 0.30 \\
\hline Salt & 0.20 & 0.20 & 0.20 & 0.20 \\
\hline Total & 100.00 & 100.00 & 100.00 & 100.00 \\
\hline Price(USD)/kg & 0.28 & 0.29 & 0.30 & 0.31 \\
\hline
\end{tabular}

$\mathrm{PO}=$ Palm oil; $\mathrm{SO}=$ Sunflower oil

\section{RESULTS AND DISCUSSION}

\section{Chemical Composition of Experimental Diets}

The chemical compounds of the diets are shown in Table 2. Chemical compositions of the TMR in each dietary treatment were similar. The percentages of EE contents in the TMRs were 4.50, 5.11, 5.20 and 4.95 , while CP contents were $14.35,14.40,13.92$ and $13.81 \%$ respectively.

\section{Daily Dry Matter and Nutrient Intakes}

Generally, the high intake of fats certainly depresses feed intake as a result of the inhibition of rumen movement (Chilliard, 1993). In the current experiment, feed intake was unaltered, and ruminant nutrition recommends total fat should not be extreme i.e. 6-7\% of dietary dry matter without a negative effect on the nutrient digestion (Jenkins, 1993). Therefore, it was found that fat source supplementation was not affected by the total dry matter intake $\left(\mathrm{kg} /\right.$ day and $\left.\mathrm{g} / \mathrm{kgBW}^{0.75}\right)$ of cattle (Table 3 ) which is confirmed by Thanh et al. (2018), who fed goats with Guinea grass with concentrate including $25 \mathrm{~g} / \mathrm{kg}$ of SFO with total fat in the feed being $4.63 \%$ in diet and this did not affect feed intake. All treatments did not affect DM intake/kgW0.75 and DM intake as a \% of BW and this agrees with Otaru et al. (2011) who suggested an addition of $4 \%$ palm oil in concentrate for goats.

Intakes of DM, OM, CP, EE and NDF were not significantly different across the diets ( $\mathrm{P}>0.05$ ) according to Markus et al. (1996) who suggested that, when supplemented with $7.1 \%$ whole sunflower seeds ( $4.2 \%$ total fat) in the diet of Holstein cows, this did not influence the intakes of NDF and ADF. Additionally, Thanh et al. (2018) suggested that replacing SFO with fish oil (FO) with total fat $4.5 \%$ approximately in the diet of growing goats did not significantly affect the intakes of DM, OM, CP and EE. Nevertheless, the ADF intake of bagasse was higher $(\mathrm{P}<0.01)$ 
Table 2. Chemical Compositions of TMR (DM Basis)

\begin{tabular}{|c|c|c|c|c|}
\hline \multirow{2}{*}{$\begin{array}{c}\text { Chemical Composition } \\
(\%)\end{array}$} & \multicolumn{2}{|c|}{ Bagasse } & \multicolumn{2}{|c|}{ Rice straw } \\
\hline & $\mathrm{PO}$ & $\mathrm{SO}$ & $\mathrm{PO}$ & $\mathrm{SO}$ \\
\hline DM & 91.20 & 92.55 & 89.94 & 90.67 \\
\hline $\mathrm{OM}$ & 89.83 & 90.78 & 88.36 & 89.65 \\
\hline $\mathrm{EE}$ & 4.50 & 5.11 & 5.20 & 4.95 \\
\hline $\mathrm{CP}$ & 14.35 & 14.40 & 13.92 & 13.81 \\
\hline NDF & 51.33 & 53.50 & 54.78 & 56.86 \\
\hline $\mathrm{ADF}$ & 25.96 & 28.77 & 21.89 & 20.45 \\
\hline Crude ash & 10.17 & 9.22 & 11.64 & 10.35 \\
\hline TDN & 66.50 & 63.26 & 65.18 & 64.83 \\
\hline
\end{tabular}

$\mathrm{PO}=$ palm oil; $\mathrm{SO}=$ Sunflower oil; $\mathrm{DM}=$ Dry matter; $\mathrm{OM}=$ Organic matter; $\mathrm{EE}=$ Ether extract; $\mathrm{CP}=\mathrm{Crude}$ protein; $\mathrm{NDF}=$ Neutral detergent fibre; $\mathrm{ADF}=$ Acid detergent fibreTDN $=$ Total digestible nutrient

Table 3. Daily Dry Matter Intake (kg/d) and Nutrient Intake (kg/d) in Bulls Fed Different Diets

\begin{tabular}{|c|c|c|c|c|c|c|c|c|}
\hline \multirow{3}{*}{ Items } & \multicolumn{4}{|c|}{ Diets } & \multirow{3}{*}{ SEM } & \multicolumn{3}{|c|}{ P-value } \\
\hline & \multicolumn{2}{|c|}{ Bagasse } & \multicolumn{2}{|c|}{ Rice Straw } & & \multirow{2}{*}{$\mathrm{RS}$} & \multirow{2}{*}{ OILS } & \multirow{2}{*}{ RS*OILS } \\
\hline & $\mathrm{PO}$ & $\mathrm{SO}$ & $\mathrm{PO}$ & $\mathrm{SO}$ & & & & \\
\hline \multicolumn{9}{|c|}{ Total DM Intake } \\
\hline $\mathrm{kg} / \mathrm{d}$ & 4.60 & 4.91 & 4.66 & 4.69 & 0.22 & ns & ns & ns \\
\hline $\mathrm{g} / \mathrm{kgBW}^{0.75}$ & 54.11 & 55.37 & 54.40 & 53.27 & 1.94 & ns & ns & ns \\
\hline$\% \mathrm{BW}$ & 2.24 & 2.33 & 2.26 & 2.34 & 0.04 & ns & ns & ns \\
\hline \multicolumn{9}{|c|}{ Nutrient Intake (kg/day) } \\
\hline $\mathrm{OM}$ & 4.20 & 4.55 & 4.19 & 4.25 & 0.20 & ns & ns & ns \\
\hline $\mathrm{CP}$ & 0.66 & 0.71 & 0.65 & 0.65 & 0.03 & ns & ns & ns \\
\hline EE & 0.21 & 0.25 & 0.24 & 0.23 & 0.01 & ns & ns & ns \\
\hline NDF & 2.36 & 2.63 & 2.55 & 2.67 & 0.12 & ns & ns & ns \\
\hline $\mathrm{ADF}$ & 1.19 & 1.42 & 1.02 & 0.96 & 0.05 & $* *$ & ns & ns \\
\hline
\end{tabular}

$\mathrm{PO}=$ palm oil; $\mathrm{SO}=$ Sunflower oil; $\mathrm{OM}=$ Organic matter; $\mathrm{CP}=$ Crude protein; $\mathrm{EE}=$ Ether extract; $\mathrm{NDF}=$ Neutral detergent fibre; $\mathrm{ADF}=$ Acid detergent fibre; $\mathrm{PO}=$ palm oil; $\mathrm{SO}=$ Sunflower oil; $\mathrm{RS}=$ roughage sources; $\quad \mathrm{SEM}=$ standard error of the mean; $\mathrm{ns}=$ not significant. ${ }^{*} * \mathrm{P}<0.01$

than in the rice straw of the bulls due to ADF in TMRs with bagasse supplemented with PO and SFO which contained higher ADF than TMRs with rice straw supplemented with PO and SFO
(Table 3).

\section{Apparent Digestibility of Nutrients}

No significant differences were observed for 
the digestibility of DM, CP, EE and NDF and ADF in beef cattle being fed either bagasse or rice straw with PO or sunflower SFO based TMR (Table 4). In the present experiment, the oil supplementation was almost $5.0 \%$ and that is not high enough to sufficiently depress the feed intake because it is less than the safe level for microbial activity in the rumen (Morsy et al., 2015). Normally, the ruminant nutritionists recommend the total fat in the diet to be below $6 \%$ of the DM. Moreover, the digestibility of DM and CP in this present experiment was lower than Thanh et al. (2018) who supplemented $25 \mathrm{~g} / \mathrm{kg}$ DM sunflower oil in growing goats, DM digestibility was $70.29 \%$, and CP digestibility was $80.77 \%$, respectively. Additionally, Wachirapakorn et al. (2016) reported that cows fed ground corn cobs $(33 \%)$ and rice straw $(7 \%)$ in TMR, NDF digestibility was $63.40 \%$ and $52.60 \%$ respectively. However, for EE digestibility this experiment was approximately $86.36 \%$ lower than Polviset et al. (2015) who suggested that $97.50 \% \quad \mathrm{EE}$ digestibility in Thai native bulls fed with sunflower seed. It might be reasoned that oil seeds may not negatively affect nutrients' digestibility.

\section{Blood Chemistry}

In this experiment (Table 5) plasma glucose concentrations ranging between 85.50-92.00 $\mathrm{mg} / \mathrm{dl}$ were higher than reported from Kholif et al. (2018) who fed goats with $20 \mathrm{ml}$ of flaxseed oil in concentrate (blood glucose was $68.90 \mathrm{mg} / \mathrm{dl}$ ) and Civelek et al. (2011) suggested serum glucose ranging from $49.79-59.00 \mathrm{mg} / \mathrm{dl}$. However in a study, plasma glucose did not find any effect when the beef cattle were supplemented with different diets.

In this experiment, the range of plasma cholesterol concentrations did not differ significantly $(\mathrm{P}>0.05)$ from the treatments. The range in between $88.00-134.75 \mathrm{mg} / \mathrm{dl}$ were lower than Otaru et al. (2011) who reported the range of serum cholesterol concentrations of 122.30$186.15 \mathrm{mg} / \mathrm{dl}$ when an increased level of palm oil were included in goats. On the other hand, Tudisco et al. (2019) who fed TMR supplemented with hydrogenated palm oil in dairy goats, cholesterol concentration was $70.16 \mathrm{mg} / \mathrm{dl}$ in agreement with our results, when fed TMR with rice straw and sunflower oil, cholesterol concentration was $88 \mathrm{mg} / \mathrm{dl}$. In the other studies with dairy cows the mean concentration of cholesteryl esters was $175.40 \mathrm{mg} / \mathrm{dl}$ supplemented with TMR (formula is not shown) (Bitman et al., 1990) agree with Wheeler et al. (1987) who reported cholesterol concentration in British crossbred cattle as $162.3 \mathrm{mg} / \mathrm{dl}$.

Plasma BUN is a by-product of protein metabolism in animals. In our study, the treatments were not significant, and 15.85-19.63 $\mathrm{mg} / \mathrm{dl}$ lower than Javaid et al. (2008) who suggested that for medium ruminally, degradable protein fed buffalo bulls the BUN concentration was $22.77 \mathrm{mg} / \mathrm{dl}$, and Tudisco et al. (2019) reported that when fed hydrogenated palm oil at $50 \mathrm{~g} /$ day in dairy goats the BUN concentration was $38.96 \mathrm{mg} / \mathrm{dl}$. However, the BUN concentration in this study was in the normal

Table 4. Apparent Digestibility of Nutrients

\begin{tabular}{|c|c|c|c|c|c|c|c|c|}
\hline \multirow{3}{*}{ Items } & \multicolumn{4}{|c|}{ Diets } & \multirow{3}{*}{ SEM } & \multicolumn{3}{|c|}{ P-value } \\
\hline & \multicolumn{2}{|c|}{ Bagasse } & \multicolumn{2}{|c|}{ Rice Straw } & & \multirow{2}{*}{$\mathrm{RS}$} & \multirow{2}{*}{ OILS } & \multirow{2}{*}{ RS*OILS } \\
\hline & $\mathrm{PO}$ & SO & $\mathrm{PO}$ & $\mathrm{SO}$ & & & & \\
\hline $\mathrm{DM}$ & 67.74 & 65.77 & 69.00 & 64.37 & 1.67 & ns & ns & ns \\
\hline $\mathrm{CP}$ & 62.09 & 62.58 & 65.13 & 61.54 & 1.14 & ns & ns & ns \\
\hline $\mathrm{EE}$ & 83.32 & 87.63 & 87.17 & 87.33 & 1.25 & ns & ns & ns \\
\hline NDF & 64.52 & 53.52 & 66.16 & 60.84 & 1.73 & ns & ns & ns \\
\hline $\mathrm{ADF}$ & 53.57 & 56.23 & 58.09 & 54.37 & 1.70 & ns & ns & ns \\
\hline
\end{tabular}

$\mathrm{PO}=$ palm oil; $\mathrm{SO}=$ Sunflower oil; $\mathrm{DM}=$ Dry matter; $\mathrm{CP}=$ Crude protein; $\mathrm{EE}=$ Ether extract; $\mathrm{NDF}=$ Neutral detergent fibre; $\mathrm{ADF}=$ Acid detergent fibre; $\mathrm{RS}=$ roughage sources; $\mathrm{SEM}=$ standard error of the mean; $\mathrm{ns}=$ not significant 
Table 5. Blood Chemistry Parameters in Bulls

\begin{tabular}{|c|c|c|c|c|c|c|c|c|}
\hline \multirow{3}{*}{$\begin{array}{l}\text { Items } \\
(\mathrm{mg} / \mathrm{dl})\end{array}$} & \multicolumn{4}{|c|}{ Diets } & \multirow{3}{*}{ SEM } & \multicolumn{3}{|c|}{ P-value } \\
\hline & \multicolumn{2}{|c|}{ Bagasse } & \multicolumn{2}{|c|}{ Rice straw } & & \multirow{2}{*}{ RS } & \multirow{2}{*}{ OILS } & \multirow{2}{*}{ RS*OILS } \\
\hline & $\mathrm{PO}$ & $\mathrm{SO}$ & $\mathrm{PO}$ & $\mathrm{SO}$ & & & & \\
\hline Plasma glucose & 91.50 & 92.00 & 86.25 & 85.50 & 5.24 & ns & ns & ns \\
\hline BUN & 19.63 & 18.28 & 17.63 & 15.85 & 3.55 & ns & ns & ns \\
\hline Cholesterol & 111.75 & 134.75 & 104.75 & 88.00 & 13.71 & ns & ns & ns \\
\hline Triglycerides & 28.00 & 37.00 & 19.25 & 28.00 & 6.62 & ns & ns & $\mathrm{ns}$ \\
\hline
\end{tabular}

$\mathrm{PO}=$ palm oil; $\mathrm{SO}=$ Sunflower oil; $\mathrm{RS}=$ roughage sources; $\mathrm{BUN}=$ Blood urea nitrogen; $\mathrm{SEM}=$ standard error of the mean; ns = not significant

range of BUN (2.9 to $22.4 \mathrm{mg} / \mathrm{dl}$.) (Lane and Campbell, 1966).

Additionally, feed supplementation with the type and amount of dietary fat was an influence on the value of triglycerides in plasma (Clemens et al., 1974; Ghoreishi et al., 2007). The range of triglycerides concentration was $19.25-37.00 \mathrm{mg} / \mathrm{dl}$ in this experiment, higher than Civelek et al. (2011) who recommended serum triglycerides from 10.17-12.42 mg/dl, and Tudisco et al. (2019) who fed TMR supplemented with hydrogenated palm oil in dairy goats with triglycerides concentration was $20.12 \mathrm{mg} / \mathrm{dl}$. Nevertheless, Kholif et al. (2018) reported that triglycerides concentration was $131.80 \mathrm{mg} / \mathrm{dl}$ when fed $20 \mathrm{ml}$ of flaxseed oil in goats. However, overall the circulating lipids in ruminants were fluctuating depending on the feed supplementation.

\section{CONCLUSION}

The results of this experiment indicated that the addition of roughage sources from either bagasse or rice straw $(40 \%)$ in the TMR containing concentrate $(60 \%)$ with palm oil or sun flower oil were carried out without any effect on DMI, digestibility and blood chemistry. However, using bagasse with palm oil was suitable in beef cattle diets due to the lowest price $(0.28 \mathrm{USD} / \mathrm{kg})$.

\section{ACKNOWLEDGMENTS}

The authors would like to express their appreciation for research funding in 2016 with Contract No 170476 from National research council of Thailand and facilities resources to the
Research and Development institute and Program in Animal Science Faculty of Agricultural and Technology, Rajabhat Maha Sarakham University, Thailand.

\section{REFERENCES}

AOAC. 1984. Official methods of analysis. The $14^{\text {th }}$ ed. The Association of Official Analytical Chemists. Washington, D.C.

Baiti, L.Z., L.K. Nuswantara, E. Pangestu, F. Wahyono and J. Achmadi. 2013. Effect of bagasse portion in diet on body composition of goat. J. Indonesian Trop. Anim. Agric. 38(3): 199-204

Bauman, D.E., J.W. Perfield, M.J. De Veth and A.L. Lock. 2003. New perspectives on lipid digestion and metabolism in ruminants. Proc. Cornell Nutr. Conf. 175-189.

Bitman, J., D.L. Wood and A.M. Lefcourt. 1990. Rhythms in cholesterol, cholesteryl esters, free fatty acids, and triglycerides in blood of lactating dairy cows. J. Dairy Sci. 73(4):948955

Chilliard, Y. 1993. Dietary fat and adipose tissue metabolism in ruminants, pigs, and rodents: a review. J. Dairy Sci. 76(12): 3897-3931

Civelek, T., I. Aydin, C.C. Cingi, O. Yilmaz and M. Kabu. 2011. Serum non-esterified fatty acids and beta-hydroxybutyrate in dairy cows with retained placenta. Pak Vet J. 31(4): 341-344.

Clemens, E., W. Woods and V. Arthaud. 1974. The effect of feeding unsaturated fat as influenced by the presence or absence of rumen protozoa. I serum lipid composition. 
J. Anim. Sci. 38(3): 634-639.

Ghoreishi, S.M., M.J. Zamiri and E. Rowghani. 2007. Effect of a calcium soap of fatty acids on reproductive characteristics and lactation performance of fat-tailed sheep. Pakistan J Biol Sci. 10(14): 2389-2395

Goering, H. K. and P. J. Van Soeast. 1970. Forage Fiber Analyses (apparatus, reagents, procedures and some applications). Agric. Handbook No. 379. AR. USDA. Washington, D.C.

Jenkins, T.C. 1993. Lipid metabolism in the rumen. J. Dairy Sci. 76(12): 3851-3863

Kholif, A.E., T.A. Morsy and M.M. Abdo. 2018. Crushed flaxseed versus flaxseed oil in the diets of Nubian goats: effect on feed intake, digestion, ruminal fermentation, blood chemistry, milk production, milk composition and milk fatty acid profile. Anim. Feed Sci. Technol . 244(1) : 66-75

Lane, A. G. and J. R. Campbell. 1966. Blood urea nitrogen in Guernsey cattle. J. Dairy Sci. 49(2): 193-194

Markus, S.B., K.M. Wittenberg, R. Ingalls and M. Undi. 1996. Production responses by early lactation cows to sunflower seed or tallow supplementation of a diet based on barley. J. Dairy Sci. 79(10): 1817-1825

Moloney, A.P. and P. O'Kiely. 1997. Digestibility, nitrogen retention and plasma metabolite concentrations in steers offered whole-crop wheat silage-based rations. Irish J. Agri. Food Res. 36(2) : 135-144

Morsy, T.A., S.M. Kholif, A.E. Kholif, O.H. Matloup, A.Z.M. Salem and A. Abu Elella. 2015. Influence of sunflower whole seeds or oil on ruminal fermentation, milk production, composition, and fatty acid profile in lactating goats. Asian-Australasian J. Anim. Sci. 28(8):1116-1122.

Nguyen, V.H., B.O. Sander, J. Quilty, C. Balingbing, A.G. Castalone, R. Romasanta, M.C.R. Alberto, J.M. Sandro, C. Jamieson and M. Gummert. 2019. An assessment of irrigated rice production energy efficiency and environmental footprint with in-field and of-field rice straw management practices . Sci. Rep. 9:1-12

Otaru, S.M., A.M. Adamu, O.W. Ehoche and H.J. Makun. 2011. Effects of varying the level of palm oil on feed intake, milk yield and composition and postpartum weight changes of Red Sokoto goats. Small Rumin. Res. 96(1):25-35
Polviset, W., J.T. Schonewille, H. Everts, C. Wachirapakorn, C. Yuangklang, E. Claeys and S. De Smet. 2015. Effect of whole cottonseed $v$. sunflower seed on the fatty acid profile of subcutaneous fat, longissimus dorsi and blood of Thai Native and Holstein bulls. Anim. 9(12):2072-2080

SAS. 2000. User's guide: statistics. Version 7. SAS Institute. Cary. New York.

Seshaiah, C.V.,Y. R. Reddy, S.J. Rao and M. Srivani. 2014. Prediction of optimum roughage to concentrate ratio in sweet sorghum (Sorghum bicolor L. Moench) bagasse based total mixed ration for buffaloes using in vitro gas technique. J. Adv. Vet. Anim. Res. 1(4): 224-227

Sommart, K., M. Wanapat, P. Rowlinson, D. S. Parker, P. Climee and S. Panishying. 2000. The use of cassava chips as an energy source for lactating dairy cows fed with rice straw. Asian-Australas J Anim Sci. 13(8):10941101.

Steel, R.G.D. and J.H. Torrie. 1980. Principles and Procedures of Statistics. McGraw-Hill Book Co. Inc. New York.

Thanh, L.P., N. Phakachoed, C. Meeprom and W. Suksombat. 2018. Replacement of fish oil for sunflower oil in growing goat diet induces shift of ruminal fermentation and fatty acid concentration without affecting intake and digestion. Small Rumin. Res. 165:71-78.

Tudisco, R., N. Musco, M.E. Pero, V.M. Morittu, M. Grossi, V. Mastellone, G. Cavaliere, M. Wanapat, F. Infascelli and P. Lombardi. 2019. Influence of dietary hydrogenated palm oil supplementation on serum biochemistry and progesterone levels in dairy goats. Anim. Nutr. 5(3): 286-289.

Van Soest, P.J. 1994. Nutritional ecology of the ruminant. $2^{\text {nd }}$ ed. Cornell University Press Ithaca. New York.

Javaid, A., M. Mahr-un-Nisa, M. Sarwar and A. Shahzad. 2008. Ruminal characteristics, blood $\mathrm{pH}$, blood urea nitrogen and nitrogen balance in Nili-ravi Buffalo (Bubalus bubalis) bulls fed diets containing various levels of ruminally degradable protein. Asian-Aust. J. Anim. Sci. 21(1):51-58.

Wachirapakorn, C., K. Pilachai, M. Wanapat, P. Pakdee and A. Cherdthong. 2016. Effect of ground corn cobs as a fiber source in total mixed ration on feed intake, milk yield and milk composition in tropical lactating 
crossbred Holstein cows. Anim. Nutr. 2(4): 334-338

Wheeler, T.L., G.W. Davis, B.J. Stoecker and C.J. Harmon. 1987. Fat and serum of two beef cattle breed types cholesterol concentration of longissimus muscle, subcutaneous. J. Anim. Sci. 65(6): 1531-1537. 